Arch. histol. jap., Vol. 40, Suppl. (1977)

p. $231-239$

Department of Anatomy (Prof. M. MAto), Jichi Medical School, Minamikawachi, Tochigi, Japan

\title{
Monoamine-Storing Cells in the Avian Aortic Wall
}

\author{
Shigeo OoKawara
}

Summary. Using the FALCK-HILlaRP method, monoamine-storing cells were demonstrated in the avian thoracic aorta just above the openings of the ductus arteriosus. By electron microscopy, numerous dense-cored vesicles, 90-220 $\mathrm{nm}$ in diameter, were seen in the cytoplasm. The electron opacity of these dense-cored vesicles was reduced when reserpine $(5 \mathrm{mg} / \mathrm{kg})$ was administered. These monoamine-storing cells formed typical synapses with the Schwann cell-enclosed nerve terminals.

The monoamine-storing cells first appeared in the aortic wall at 9 days in ovo but it remained obscure whether they originated from the neuroectoderm.

\section{Monoamine-storing cells in the avian thoracic aorta}

Kose (1903) reported the existence of paraganglia in the abdominal aorta of the crow. Later, similar paraganglia were also reported in the thoracic aorta just above the openings of the ductus arteriosus in young chicks (PALM, 1934; Muratori, 1962). In 1953, Chowdhary described the "epithelioid cells" in the common carotid artery near the carotid body of the chicken. However, it seems likely that the epithelioid cells of CHOwdhary (1953) are the same as the paraganglion cells of Kose (1903), Palme (1934) and Muratori (1962). Recently, using the flourescence histochemical method of FAlck and HillarP (1962), monoamines (serotonin or catecholamines) have been detected in these paraganglionic or epithelioid cells (KoBAyAsHI, 1971; BenNETT, 1971; OoKAwARA et al., 1974); hence, they are called monoamine-storing cells in this article.

In birds, examined by us (chicken, pigeon, love-bird and sparrow), the monoamine-storing cells are located in the thoracic aorta just above the openings of the ductus arteriosus in the fetal stage (or at the root of ligamentum arteriosum in the adult). In the ordinary histological specimen (e.g. that stained with Weigert's resorcin-fuchsin), these cells are easily recognized as interruptions of the elastic fibers in the aortic wall (Fig. 1). In the aortic media, they occur singly or in groups. They are often located in the subendothelial layer (Fig. 3). Occasionally, covered by endothelial cell, they protrude into the vascular lumen (OoKAwARA et al., 1974). In the outer half of the media, bundles of elongated cells are observed. Nerve fibers are present here (Fig. 2); they innervate the monoamine-storing cells in the inner media (Fig. 2) as pointed out by Nonidez (1935) and OoKAwArA et al. (1974). In mammals, so far examined (rabbit, rat), no monoamine-storing cells have been found (OoKawara, unpublished).

\section{Fine structure}

By light microscopy, monoamine-storing cells are about $15 \mu \mathrm{m}$ in diameter, and are characterized by a clear cytoplasm and an oval nucleus which is poor in chromatin (Fig. 3) (OoKawara et al., 1974). 

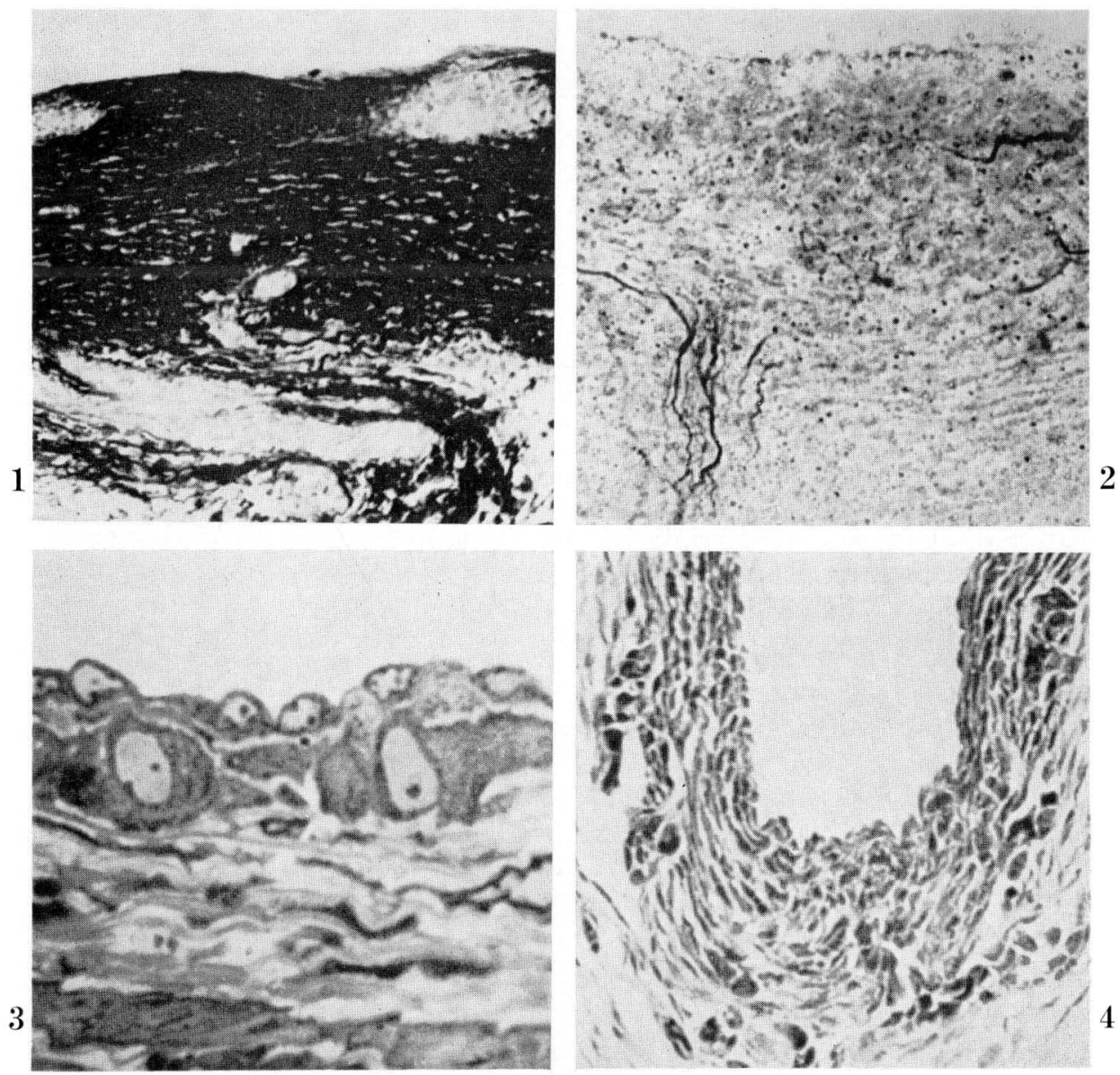

Fig. 1. Monoamine-storing cells are situated in the interrupted parts of elastic fibers. A bundle of elongated cells are seen in the adventitia and outer media. Weigert's elastic fiber stain. $\times 300$. All figures are photographed from the aorta of chickens.

Fig. 2. Nerve fibers extending from the adventitia to inner media. Nerve fiber staining by ÁBRAHÁM's (1968) method. $\times 300$

Fig. 3. The monoamine-storing cells in subendothelial layer. Epon-embedding. Toluidine blue stain. $\quad \times 1,500$

Fig. 4. Aorta from 10 day chick embryo. The monoamine-storing cells are situated in the adventitia and outer media. $\times 120$

Electron microscopic observation (OoKawara et al., 1974; Kondo, 1974) shows the presence of numerous dense-cored vesicles, $90-220 \mathrm{~nm}$ in diameter, in the cytoplasm (Fig. 5). The cores are spherical or ovoid in shape and are bound by a limiting membrane with a clear peripheral zone (Fig. 6, 7, 8). Density of the cores varies from vesicle to vesicle. Cores of relatively low density show a fine granular texture (Fig. 7, 8). The Golgi apparatus is located in the perinuclear region. Thus, the cytological characteristics of monoamine-storing cells found in the avian thoracic aorta are fundamentally similar to those of the chief cells of the carotid body (Hess, 
1968), of SIF cells in autonomic ganglia (ELFVIN, 1968), and of cells in the neuroepithelial bodies in the respiratory mucosa (LAUwERYNS et al., 1972).

No figures of exocytosis have been obtained. However, this does not indicate that secretory function in the monoamine-storing cells is absent. Further studies

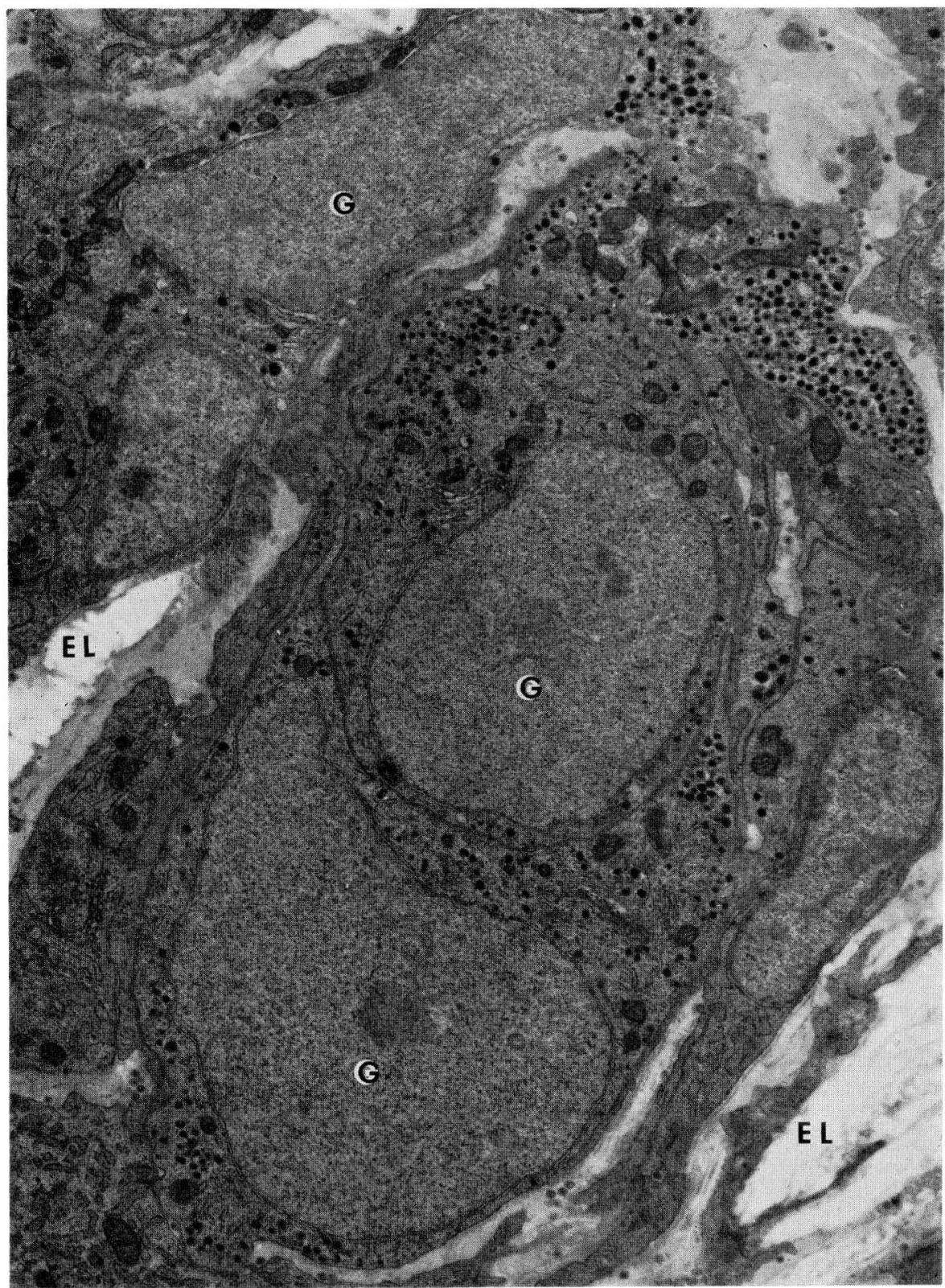

Fig. 5. Electron micrograph of monoamine-soring cells in the aortic wall. G indicates monoamine-storing cell. $E L$ elastic fibers in aortic media. $\times 8,000$ 


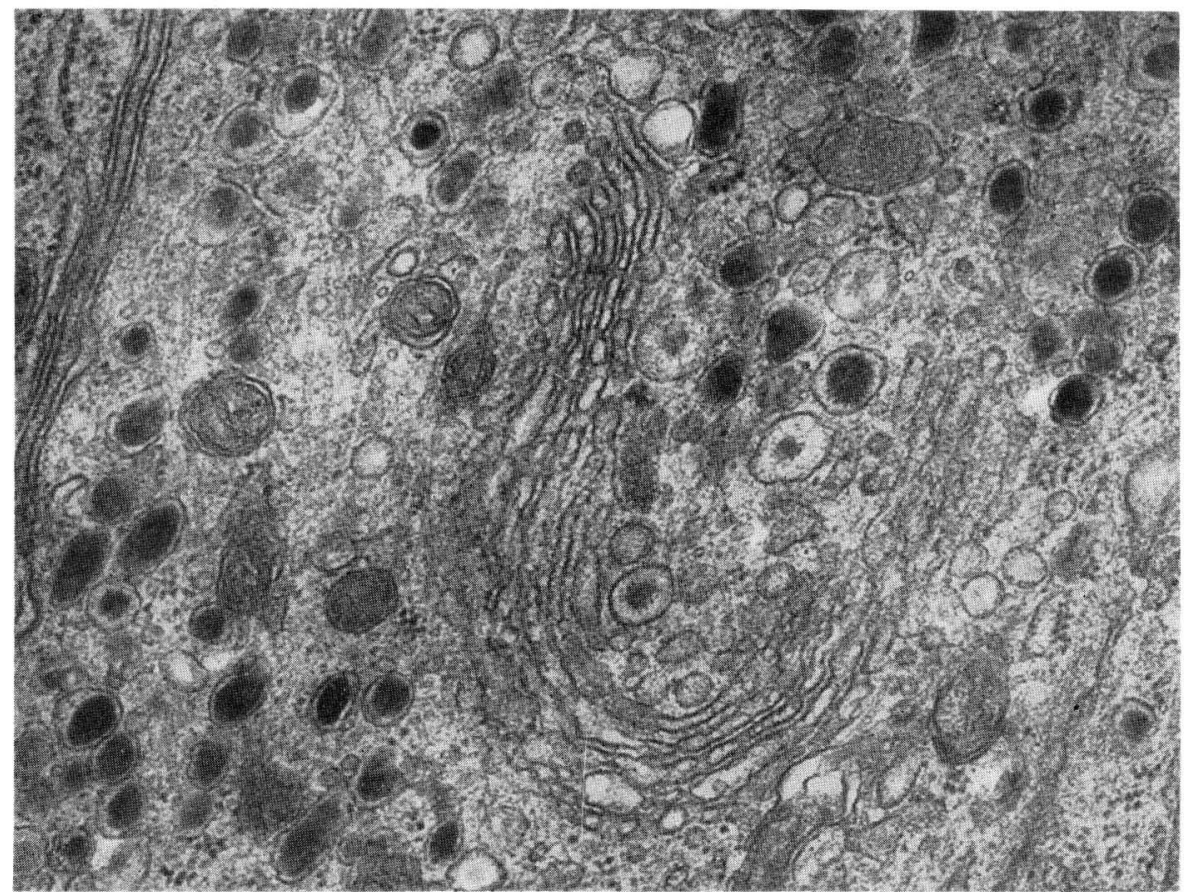

Fig. 6. Golgi area of the monoamine-storing cell. Notice that the cores of the vesicles are smaller in size and paler in electron density than those in the periphery of the cell. $\times 40,000$

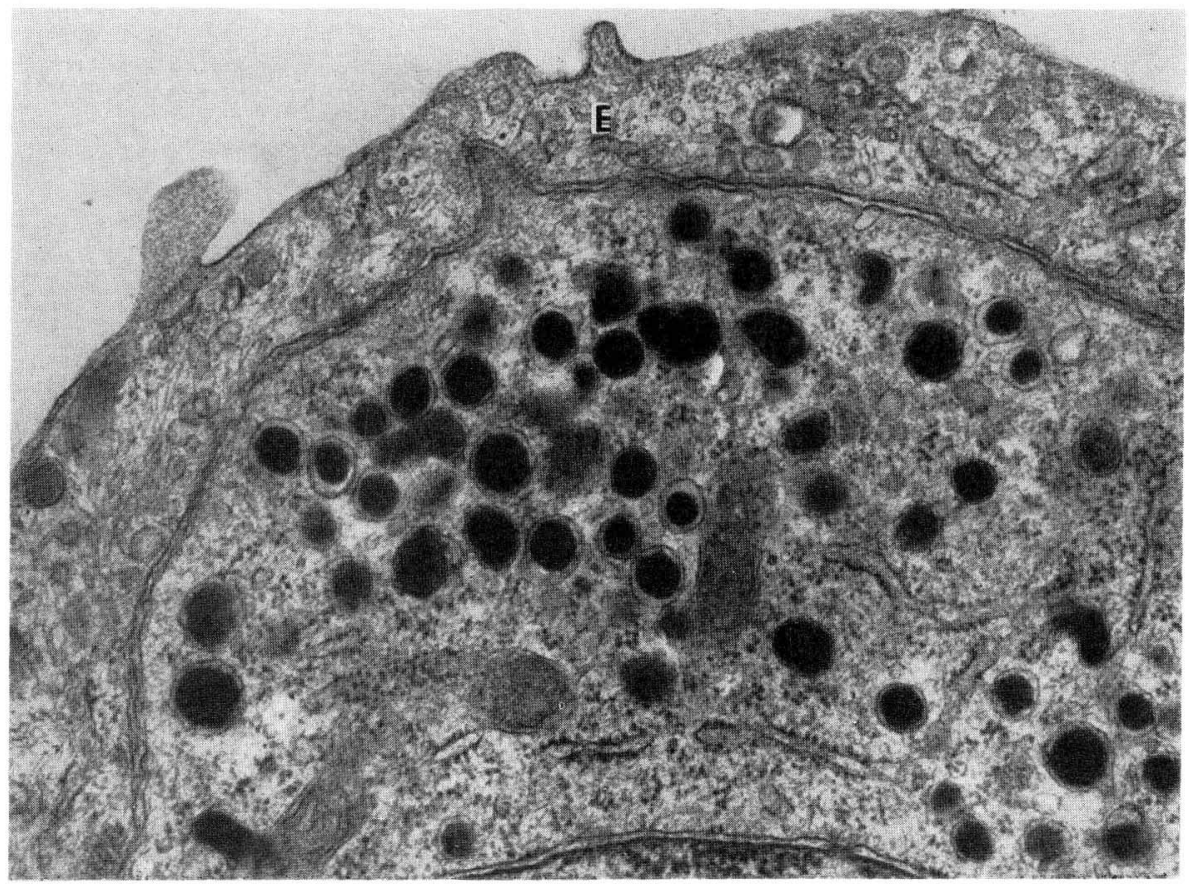

Fig. 7. Monoamine-storing cell in close contact with endothelial cell. $E$ endothelial cell. $\times 40,000$ 


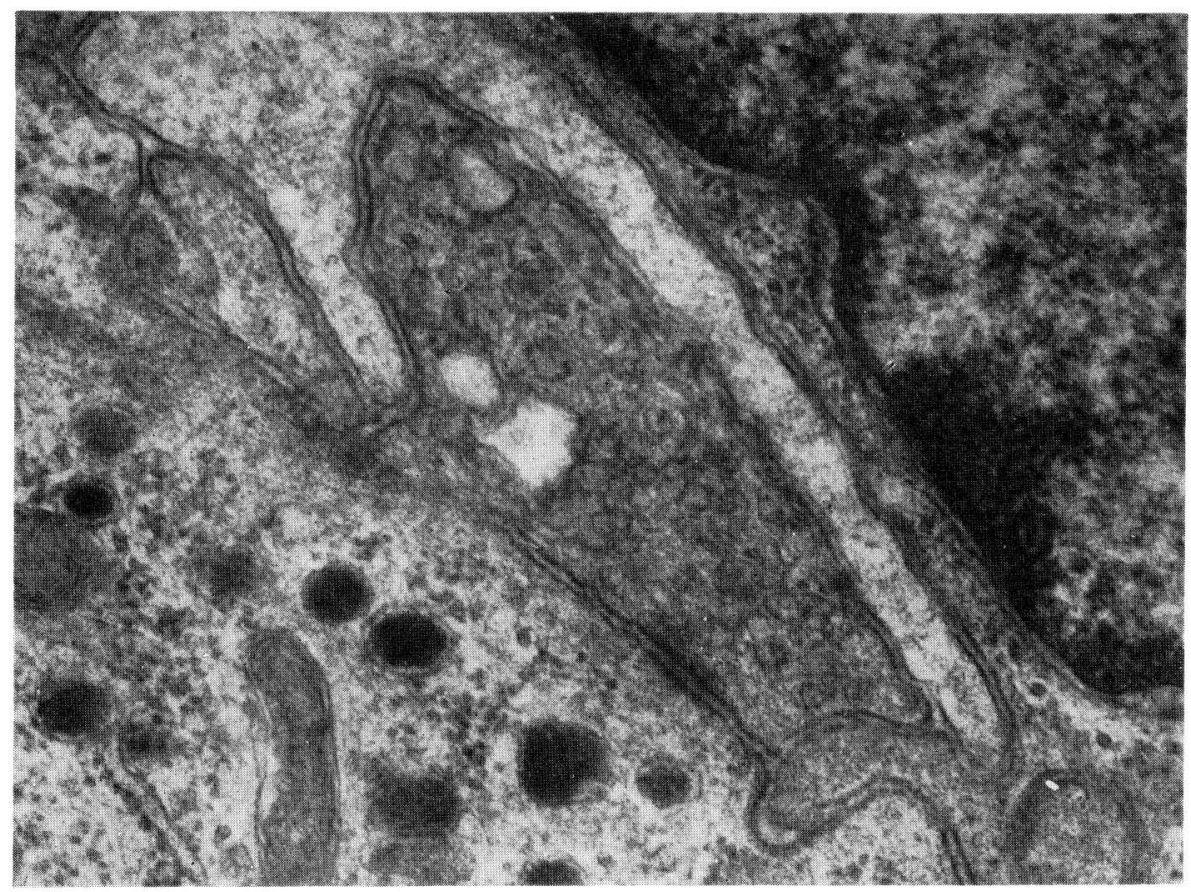

Fig. 8. A nerve ending containing small clear vesicles synapses on the monoamine-storing cell. $\times 45,000$

will surely demonstrate clear-cut exocytotic figures.

As shown in Figure 7, the monoamine-storing cells are in close apposition with endothelial cells or with smooth muscle cells in the aortic media. If these cells release any bioactive substances (serotonin or catecholamine), the secretory substance probably passes through the endothelial cells and exerts a blood-born effect. If it is released into the aortic wall, then it may exert a direct effect on smooth muscle cells.

\section{The response of monoamine-storing cells to reserpine}

When reserpine is administered to chickens $(5 \mathrm{mg} / \mathrm{kg})$, monoamine-storing cells exhibit marked alterations in the cored vesicles. The electron opacity of the cores is markedly reduced in the central part. Furthermore, vesicles with cores of lowelectron density increase in number (Fig. 9, 10) (Ookawara et al., 1974). This may indicate a diminution in the monoamine content in the cores of these vesicles.

\section{Innervation of monoamine-storing cells}

As described above, silver impregnation techniques demonstrated that nerve fibers may innervate the monoamine-storing cells (Nonidez, 1935; OoKawara et al., 1974).

By electron microscopy, nerve fibers terminate on monoamine-storing cells forming typical synapses (Fig. 8). Synaptic terminals contain mitochondria and electron lucent synaptic vesicles. Synaptic vesicles aggregate only at the margins of the 
nerve terminals which are, therefore, considered to be efferent in nature (OoKAwARA et al., 1974). In addition to this type of nerve terminal, Kondo (1974) reported a nerve terminal which contained granular synaptic vesicles.

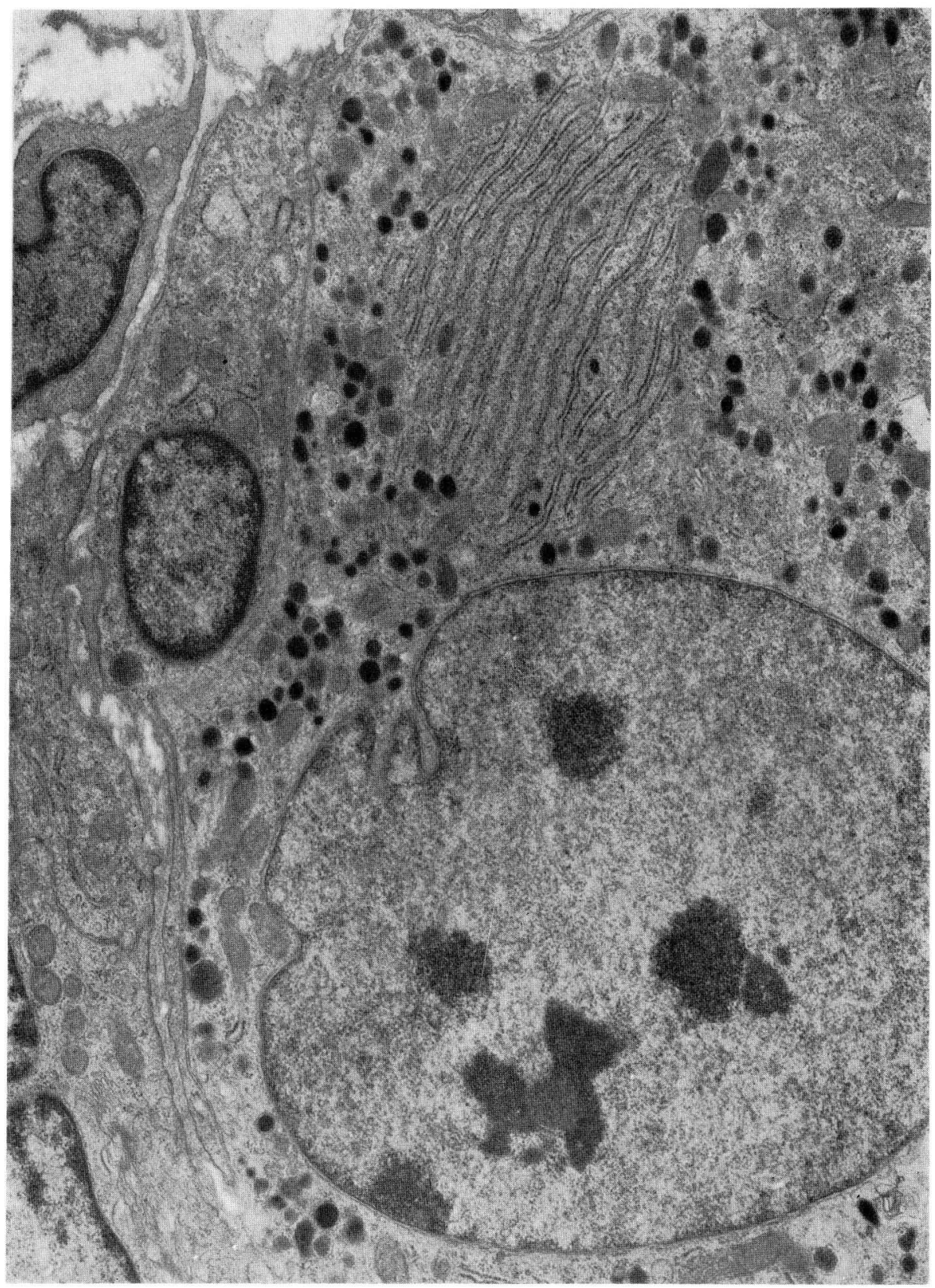

Fig. 9. A monoamine-storing cell in the chicken aortic wall $12 \mathrm{hrs}$ after reserpine treatment. Note the increased number of secretory granules of low electron density. $\quad \times 15,000$ 


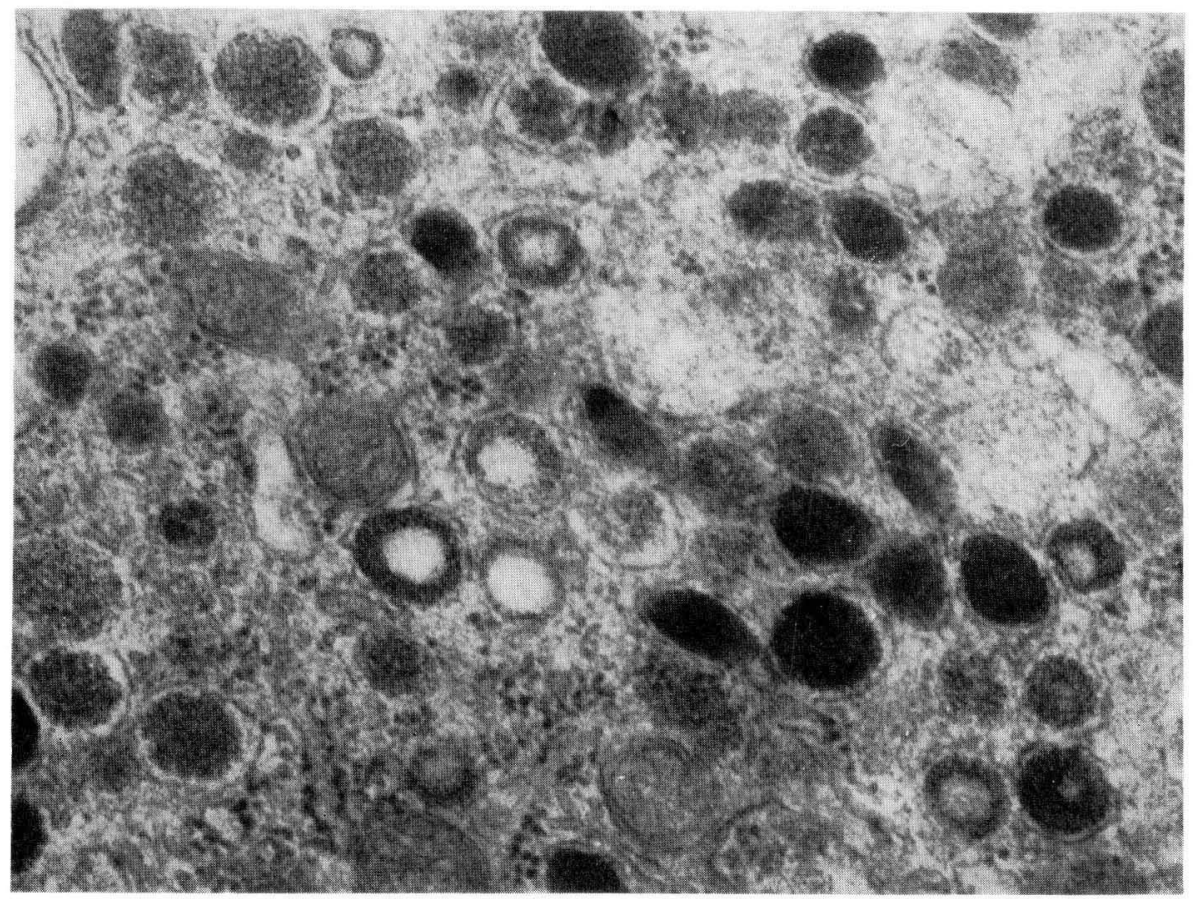

Fig. 10. Twenty-four hours after reserpine treatment. The cores of vesicles are markedly reduced in electron density. $\quad \times 48,000$

It is generally accepted that the nerve endings with an accumulation of clearcored synaptic vesicles are cholinergic, and those with granulated synaptic vesicles are adrenergic (De Robertis et al., 1963; Richardson, 1964). Based on this theory, it may be considered that monoamine-storing cells are innervated by both cholinergic and adrenergic nerve fibers. The adrenergic nerve fibers seem to correspond to the formaldehyde-induced flourescent nerve fibers reported by BENNETT (1971).

No afferent synapses on monoamine-storing cells have yet been reported. However, in the outer half of the aortic media, peculiar axon profiles with an accumulation of mitochondria were described by Kondo (1974). According to him, these sensory nerves have a chemoreceptive function.

\section{Developmental aspects of monoamine-storing cells}

In the developing chick aorta, monoamine-storing cells first appear at about 9 days in ovo (Ookawara et al., 1974). At that time, they are situated in the adventitia or the outer half of the media (Fig. 4). During developmental progress they may gradually migrate into the inner media; and finally, covered by endothelial cells, they protrude into the vascular lumen (OoKAwARA et al., 1974).

By use of electron microscopy, the cytoplasm of monoamine-storing cells of the 10 day chick embryo is characterized by abundant free ribosomes and a small number of dense-cored vesicles. In the Golgi area, small dense-cored vesicles are observed. Adhering to these cells, nerve fibers enveloped by satellite cells are observed (OoKAWARA, unpublished). Thus, the ultrastructure of the monoamine-storing cells in the 
chick embryo is similar to that of the adrenal medullary cells found in later development (Elfvin, 1967). Since it has been fairly well-established that the adrenal medullary cells originate from the neural crest, it is tempting to speculate that the monoamine-storing cells of the avian thoracic aorta, also, are of neural crest origin. However, further studies are necessary.

\title{
Conclusion
}

Recent histochemical and ultrastructual observations strongly suggested that the monoamine-storing cells in the avian thoracic aorta belong to the "paraneuron" family proposed by FuJiTA and KoBAYASHI (1975). The "paraneurons" are subdivided into endocrine, internuncial and sensory classes according to the type of innervation (YAMAUCHI, 1976). Because the location of the monoamine-storing cells in the avian thoracic aorta is similar to that of the chief cells in the carotid body, these cells may be sensory pareneurons. However, since no afferent nerve endings have been found, these monoamine-storing cells should presently be classified as an endocrine type paraneuron.

\section{鳥類の大動脈壁内にみられるモノアミン含有細胞}

\author{
大河原 重 雄
}

\footnotetext{
鳥類（ニワトリ，ハト，ジュウシマッ，スズメ）の胸大動脈壁内には特殊なモノアミン 含有細胞が存在する.

この細胞は, 細胞質内に多数の芯あり小胞を持つ. Golgi 装置近くに位置する芯あり小 胞は小型で，内容の電子密度も低い。 また，この細胞は遠心性の神経支配を受ける。 ニワ トリにレセルピン $(5 \mathrm{mg} / \mathrm{kg})$ を投与すると，電子密度の著しく低下した芯あり小胞が多 数あらわれる.

この細胞は, 胎生学的には, 9 日目の鶏胚の大動脈壁内に初めて観察された.

以上の所見から，本細胞は，藤田と小林の提唱する “パラニューロン”の範疇に属する ものであろうと推察される.
}

\section{References}

Ábrahám, A.: Species characteristics in the structure of the nervous system in the carotid body. In: (ed. by) R. W. Torrance: Arterial chemoreceptors. Blackwell, Oxford, 1968. (p. 57-63).

Bennett, T.: The adrenergic innervation of the pulmonary vasculature, the lung and the thoracic aorta, and the presence of aortic bodies in the domestic fowl (Gallus gallus domesticus L.) Z. Zellforsch. 114: 117-134 (1971).

Chowdhary, D. S. : A comparative study of the carotid body and carotid sinus of vertebrates. II. The carotid body and "carotid sinus" of the fowl (Gallus domesticus). Doctorate thesis, Edinburgh. 1-55 (1953) (cited from Kobayashi, 1971). 
De Robertis, E., G. Rodriguez de Lores Arnaz, L. Salganicoff, A. Pellegrino de Iraldi and L. M. Zieher : Isolation of synaptic vesicles and structural organization of the acetylcholine system within brain nerve endings. J. Neurochem. 10: 225-235 (1963).

Elfvin, L-G.: The development of the secretory granules in the rat adrenal medulla. J. Ultrastr. Res. 17: 45-62 (1967).

: A new granule-containing nerve cell in the inferior mesenteric ganglion of the rabbit. J. Ultrastr. Res. 22: 37-44 (1968).

Falck, B., N-A. Hillarp, G. Thieme and A. Torp : Flourescence of catecholamines and related compounds condensed with formaldehyde. J. Histochem. Cytochem. 10: 348-354 (1962).

Fujita, T. and S. Kobayashi : Paraneuron (1). (In Japanese). Igaku no ayumi (Tokyo) 94: 638-640 (1975).

Hess, A.: Electron microscopic observations of normal and experimental cat carotid bodies. In: (ed. by) R. W. Torrance: Arterial chemoreceptors. Blackwell, Oxford, 1968. (p. 51-56).

Kobayashi, S. : Comparative cytological studies of the carotid body. I. Demonstration of monoamine-storing cells by correlated chromaffin reaction and flourescence histochemistry. Arch. histol. jap. 33: 319-339 (1971).

Kondo, H. : On the granule-containing cells in the aortic wall of the young chick. Anat. Rec. 178: 253-266 (1974).

Kose, W. : Die Paraganglien bei den Vögeln. Zweiter Teil. Arch. mikrosk. Anat. 69: 665-790 (1903).

Lauweryns, J. M., M. Cokelaere and P. Theunynck: Neuro-epithelial bodies in the respiratory mucosa of various mammals. A light optical, histochemical and ultrastructural investigation. Z. Zellforsch. 135: 569-592 (1972).

Muratori, G. : Histological observations on the cervicothoracic paraganglia of amniotes. Arch. int. Pharmacodyn. 140: 217-226 (1962).

Nonidez, J. F.: The presence of depressor nerves in the aorta and carotid of birds. Anat. Rec. 62: 47-73 (1935).

Ookawara, S., K. Suzuki, Y. Yoshida and G. Ooneda : Monoamine-storing cells in the media of the thoracic aorta of Gallus domesticus. Cell Tiss. Res. 151: 309-316 (1974).

Palme, F.: Die Paraganglien über dem Herzen und im Endungsgebiet des Nervus depressor. $Z$. mikrosk.-anat. Forsch. 36: 391-420 (1934).

Richardson, K. C. : The fine structure of the albino rabbit iris with special reference to the identification of adrenergic and cholinergic nerves and nerve endings in its intrinsic muscles. Amer. J. Anat. 114: 173-206 (1964).

Yamauchi, A.: Paraneuron (7). (In Japanese). Igaku no Ayumi (Tokyo) 97: 33-35 (1976).

\author{
大河原 重 雄 \\ 产329-04 栃木県河内郡南河内町 \\ 大字薬師寺 3311-1 \\ 自治医科大学: \\ 解剖学第二講座
}

Dr. Shigeo OoKaw ARA

Department of Anatomy

Jichi Medical School,

Minamikawachi, Tochigi-ken

329-04 Japan 